\title{
ANALISA KONSEP DESAIN INTERIOR TERHADAP SEGMENTASI PADA PENGUNJUNG SEBUAH KAFE
}

\author{
Sri Wahyuni Panjaitan \\ Prodi Desain Interior \\ Fakultas Seni dan Desain Universitas Potensi Utama Medan \\ yuniwandriani@gmail.com
}

\begin{abstract}
ABSTRAK
Perkembangan bisnis kafe di kota besar seluruh Indonesia berkembang pesat dan memiliki jumlah yang banya. Salah satu perkembangan bisnis kafe di kota besar adalah Kota Medan. Kondisi ini membuat semakin bertambah pesaing produsen kafe. Para pebisnis kafe bersaing ketat untuk mencerminkan kelebihan masing-masing usaha kafe. Setiap pebisnis kafe berusaha untuk menarik perhatian dari setiap konsumen dan akan memberikan rasa kepuasan terhadap konsumen. Para pebisnis kafe memiliki strategi dalam pemasaran bisnis kafe agar dapat berjalan dan sukses untuk menghadapi persaingan bisnis kafe tersebut, mendapatkan dan menambah consumes, serta dapat mempertahankan konsumen tersebut. Strategi pemasaran yang bisa digunakan oleh pebisnis kafe salah satunya adalah layanan lingkungan fisik (servicescape). Tulisan ini menganalisis desain interior Kafe Sosmed terhadap segmentasi penunjung kafe.
\end{abstract}

Kata kunci : Kafe, desain interior

\begin{abstract}
The development of cafe business in big cities throughout Indonesia is growing rapidly and has a large number. One of the developments in the cafe business in a big city is Medan City. This condition has increased the competition of cafe producers. Cafe businessmen compete tightly to reflect the strengths of each cafe business. Every cafe businessman tries to attract the attention of every consumer and will give a sense of satisfaction to consumers. Cafe business people have a strategy in marketing the cafe business so that they can run and succeed in facing the cafe business competition, getting and adding consumables, and can retain those consumers. One of the marketing strategies that can be used by café businesses is physical services (servicescape). This paper will analyze the interior design of the Sosmed Cafe.
\end{abstract}

Keywords: Kafe, Interior design

\section{PENDAHULUAN}

Secara terminologis, kata café berasal dari bahasa Perancis-coffee, yang berarti kopi (Oldenburg, 1989: 126). Di Indonesia, kata café kemudian disederhanakan kembali menjadi kafe (Herlyana, 2012). Pengertian harafiahnya mengacu pada (minuman) kopi, yang kemudian di Indonesia kafe lebih dikenal sebagai tempat menikmati kopi dengan berbagai jenis minuman non-alkohol lainnya seperti soft drink berikut sajian makanan ringan lainnya. Senada dengan definisi kafe yang diutarakan oleh S. Medlik (1996: 30) yaitu "Café is establishment providing food and refreshment for consumption and the premises to general public". Lebih lanjut, Hornby (2005) mengartikan café (kafe) dalam dua terminologi: "a place where you can buy drink and simple meals"; yakni tempat di 
mana kita bisa membeli minuman dan makanan kecil, dan "small shop (store that sells sweets, food, newspaper, etc) usually stay open later than other shop or store"; di mana kafe lebih mengacu pada kedai atau warung yang menjual tidak hanya minuman dan makanan tetapi juga koran, buku dan buka hingga larut malam. Berdasarkan pengertian tersebut di atas kafe memiliki ciri seperti tempat yang nyaman untuk menikmati aneka makanan dan minuman berikut suasana nyaman untuk berkumpul.

Kafe ( Cafe ) merupakan salah satu tempat yag digunakan untuk berkumpul dan bersantai untuk melepas dan menghilangkan lelah serta capek setelah seharian beraktifitas. Kafe pada umumnya menyediakan makanan dan minuman. Selain itu kafe juga menyediakan live music sebagai hiburan berkumpul dan bersantai bagi para pengunjung kafe. Perbedaan antara kafe dengan tempat makan seperti restauran adalah kafe lebih mengutamakan kenyamanan pengunjung dan hiburan untuk pengunjung. Saat ini hampir semua kafe yang ada di Indonesia memiliki hiburan seperti live musik. Namun pebisnis kafe juga memperhatikan desain dan konsep dari kafe tersebut, agar pengunjung tidak bosan dan merasa lebih nyaman berada lama di kafe.

Tempat yang menyediakan makanan dan minuman yang mendekati restaurant seperti kafe memiliki pelayanan yang bagus seperti adanya hiburan music, dekorasi tempat dan konsep kafe. Dengan adanya demikian maka kafe dapat dijadikan sebagai tempat bersantai untuk berbincang-bincang dengan teman-teman, keluarga, dan rekan kantor, dan lain sebagainya. Selain tempat untuk berkumpul, bersantai, dan berbincang-bincang. Kafe bisa dijadikan anak muda sebagai tempat diskusi dan mengerjakan tugas pendidikan. Sebuah kafe yang sukses harus memenuhi persyaratan ruang dari segi keselamatan, keunikan, keamanan, kenyamanan, kenikmatan, dan kesehatan. Seiring perkembangan zaman, kafe tersebar secara luas, artinya kafe tidak hanya sebagai tempat untuk menikmati makanan dan minuman saja tetapi juga bisa menjadi tempat bersosialisasi dan mencari teman baru. Pada desain interior, konsep desain dan desain furniture yang mendukung kafe harus diperhatikan oleh pebisinis kafe agar mencapai target pengunjung. Konsep desain interior dan furniture dapat mempengaruhi para pengunjung kafe agar dapat berlama-lama menikmati kafe tersebut.

Dewasa ini, merebaknya kafe mulai jadi pemandangan sehari-hari. Dapat dilihat dengan banyaknya keberadaan kafe-kafe di tanah air. Melalui beragam penyebutan, seperti kedai kopi, coffee shop, bahkan kafe semakin menjamur pada berbagai kalangan masyarakat khususnya bagi para anak muda. Berkembangnya kafe-kafe juga didampingi dengan berbagai konsep yang dapat menarik perhatian target untuk berkunjung dan memiliki tujuan tertentu. Misalnya konsep interior, konsep lantunan musik, harga, sajian makanan dan minuman dengan tema tradisonal ataupun modern yang akan menjadikan daya tarik kafe. Hal ini membuktikan jumlah minat masyarakat terhadap hadirnya kafe yang semakin meningkat secara tidak langsung menujukkan masyarakat memiliki minat terhadap keberadaan kafe.

Salah satunya adalah fenomena menjamurnya kafe di kota Medan, di kota ini eksistensi kafe mulai diperhitungkan bagi anak-anak muda. Umumnya, kafe di sini sebagai tempat bertatap muka atau 'tempat ketiga', baik itu dengan keluarga, teman ataupun rekan bisnis. Di satu sisi, keberadaan Kota Medan sebagai titik sentral berbagai kegiatan perekonomian, pun juga terkenal sebagai tujuan destinasi wisata dan kawasan strategis dengan wisata malam seperti Lapangan Merdeka. Tidak dipungkiri, pembuktian ini kian berpengaruh terhadap kehidupan malam anak-anak muda di kota ini seperti nongkrong dan hangout. Hal ini dipahami sebagai bentuk tuntutan globalisasi yang berdampak signifikan terhadap cara hidup masyarakat. Salah satunya adalah kebutuhan untuk ajang sosialisasi dengan komunitasnya. Seiring berkembangnya zaman, kehidupan masyarakat perkotaan pun mulai mengalami perubahan gaya hidup. Salah satunya, manifestasi gaya hidup saat 
ini adalah kebiasaan nongkrong di kafe bagi kelompok masyarakat tertentu. Gaya hidup yang mengalir melalui secangkir kopi menjadikan kafe sebagai pilihan gaya hidup yang bisa didapatkan, diisi ulang, atau bahkan ditingkatkan (Tucker, 2011: 6-7). Berbagai pilihan yang ditawarkan 'tempat ngopi' menjadikan orang memiliki beragam pilihan gaya hidup baru yang lebih cair, dan disadari atau tidak menjadi bagian dari kehidupan mereka sehingga kecenderungan untuk terikat pada kegiatan ini pun cukup tinggi (Heryanto, 2008). Keberadaan orang memilih kafe sebagai tempat ketiga dengan berbagai alasan tentu menjadi fenomena yang menarik dan berdampak bagi kehidupan sosial kita, terutama soal perubahan gaya hidup, pola konsumsi, dan bentuk interaksi yang terjadi. Seakan menjadi hal yang lumrah ketika orang-orang memindahkan kegiatan sehari-hari mereka ke kafe seperti mengetik, membaca, mengobrol bersama teman, ataupun sekedar mencari hiburan.

Keberadaan kafe dalam keseharian masyarakat Kota Medan khususnya bagi anak muda telah mendapat posisi tersendiri sebagai salah satu alternatif memanfaatkan waktu luang ataupun tujuan yang lebih penting. Berbagai hal mungkin saja terjadi di dalamnya oleh setiap individu yang datang ikut memberikan kontribusi terhadap proses konsumsi ruang kafe dewasa ini. Pola konsumsi ruang yang terjadi pun dapat berubah seiring mengalirnya selera, motif dan berbagai kepentingan bagi setiap pelaku di dalamnya. Tidak hanya itu, perubahan ruang kafe dan gaya hidup juga ikut mempengaruhi bahkan mengubah pola konsumsi serta motif individu dalam mengunjungi kafe. Hal ini mengingat, tendensi gaya hidup seseorang ditentukan melalui cara memilih, menggunakan benda atau dalam proses kunsumsinya (Tomlinson, 1990: 20). Lebih jauh, dinamika yang terjadi pada pemaknaan ruang serta konsumsi berdampak pula pada sektor usaha jasa dan kuliner. Perubahan ini pun dapat mempengaruhi orientasi konsumsi seseorang sehingga kajian ini dapat digunakan sebagai salah satu sarana guna memprediksi maupun membaca arah pola konsumsi masyarakat saat ini dan yang akan datang. Elemen desain interior sebuah kafe dapat mempengaruhi pola tingkah dan sikap konsumen yang berada di dalam sebuah kafe agar konsumen betah berada berlama-lama di dalam kafe. Segmentasi pengunjung terhadap kafe dapat meliputi segmentasi prilaku. Pada segmentasi prilaku, pemasar membagi konsumen menjadi beberapa kelompok berdasarkan sikap, pengguna, atau respon terhadap sebuah produk.

Berdasarkan latar belakang di atas, penelitian ini mengenai analisa konsep desain interior sebuah kafe yang terkenal di Medan yaitu Kafe Sosmed.

\section{STUDI LITERATUR}

\section{II.1 Kajian Pustaka}

Fenomena keberadaan kafe di beberapa kota besar tanah air menarik beberapa peneliti untuk mengkajinya melalui berbagai aspek. Meskipun beberapa peneliti sebelumnya lebih memfokuskan seputar ajang promosi dan deskripsi dasar seputar eksistensi kafe dan strategi pemasarannya. Penulis mendapati beberapa penelitan yang relevan tentunya dengan pembahasan yang hendak diteliti.

Herlyana (2012) dengan penelitiannya berjudul Fenomena Coffee Shop sebagai Gejala Gaya Hidup Baru Kaum Muda mengatakan bahwa sebagian anak muda menyukai gaya hidup yang cenderung berorientasi pada nilai kebendaan dan prestise. Hal ini dilihat melalui munculnya coffee shop yang berawal dari tren meminum kopi berjenis latte dan cappucino berpengaruh pada gaya hidup anak muda yang bermula dari berubahnya lokasi ngopi. Bagaimana perubahan desain tempat, sajian kopi yang modern, dan tentunya menarik perhatian beberapa kalangan mempengaruhi kehidupan kaum muda. Adapun kesamaan dalam penelitian ini berfokus pada seputar pengalaman anak muda dan indikasi 
gaya hidup yang dilakukan. Namun, penelitian ini lebih menekankan pada keterkaitan minat anak-anak muda mengunjungi kafe.

Penelitian serupa dilakukan Salendra (2014) berjudul Coffee Shop as a Media for SelfActualization Today's Youth berupaya memperlihatkan bahwa media aktualisasi diri remaja saat ini adalah budaya nongkrong di kafe atau kedai kopi. Bentuk aktualisasi diri remaja yang dilakukan saat berada di kafe atau kedai kopi dapat berupa macam-macam hal, salah satunya dengan mengupdate status atau foto di berbagai media sosial mereka sehingga akan diketahui oleh banyak orang. Pengakuan atas diri yang eksis pada remaja didapat melalui bentuk penyesuaian tren yang ada, seperti budaya nongkrong di kafe atau kedai kopi. Kesamaan dalam penelitian ini terletak pada fokus perilaku remaja (nongkrong) yang tren dilakukan di kafe atau kedai kopi sebagai salah satu alternatif pilihan media aktualisasi diri pada anak muda.

Berikutnya, penelitian Dimyati (2009) dengan judul Komunitas Kafe sebagai Gaya Hidup (Studi Tentang Motif Mahasiswa dan Konstruksi Kuliner Kafe di Yogyakarta) menyimpulkan bahwa gerai-gerai kafe yang ada di Yogyakarta dapat membentuk suatu komunitas kafe, yang mana di dalamnya setiap mahasiswa dapat mengekspresikan bentuk kehidupannya, baik melalui kontruksi kafe sebagai suatu objek yang menarik dan diminati hingga menjadi sebuah gaya hidup. Berbeda dengan Dimyati (2009), penelitian ini berupaya menggambarkan perilaku berikut penjelasan yang berkaitan dengan bagaimana pengguna ruang kafe membawa diri mereka ke dalam ruang tersebut, sehingga berbagai peran dan perilaku secara tidak langsung menjadi bagian dari kebutuhan sosial, dan ruang kafe yang mereka kunjungi secara langsung maupun tidak menjadi panggung sosial yang memperlihatkan berbagai peran di dalamnya yang turut mendefinisikan bagaimana orang tersebut menjadikan dirinya aktor dalam sebuah drama sosial.

Berbeda halnya Kusasi (2010: 132-136) dalam bukunya berjudul Globucksisasi: Meracik Globalisasi melalui Secangkir Kopi yang melihat dari segi tinjauan budaya global. Dalam hal ini, Starbucks adalah selaku perusahaan warung kopi multinasional yang hadir dengan nuansa baru dalam menikmati secangkir kopi ala Barat di Indonesia. Bagaimana ritual meminum kopi di Indonesia dipadukan dengan jenis minuman kopi yang disiapkan dengan metode espresso bar, seperti penambahan gula, susu, karamel, foam dan ada pula yang tersaji dalam keadaan dingin sehingga kehadiran Starbucks kemudian memprakarsai budaya kafe di kota besar tanah air, yang sekaligus menjembatani kultur meminum kopi di Indonesia yang secara lokal berdialog dengan budaya asing melalui kemunculannya tersebut. Berbeda dengan Kusasi (2010), penelitian ini berupaya menjelaskan bagaimana lahirnya kultur kafe di Kota Medan terkait dengan budaya meminum kopi ala Starbucks berpengaruh tidaknya dengan motif dan tujuan anak-anak muda mengunjungi kafe-kafe yang ada.

\section{II.3 Budaya Nongkrong}

Budaya nongkrong merupakan bentuk ragam budaya yang ada di Indonesia. Keberagaman bentuk budaya tersebut dilihat sebagai sikap, cara hidup, dan nilai-nilai dalam suatu kelompok tertentu. Ini dipahami pula sebagai pola aktivitas tertentu yang sudah menjadi kebiasaan, yaitu nongkrong. Meskipun kehadirannya dipandang sebelah mata, budaya nongkrong tetap eksis menjadi bentuk ekspresi keberagaman masyarakat di kala mengisi kekosongan waktu seperti berkumpul, berbincang, dan bahkan sambil menikmati hidangan tertentu. Di satu sisi, tendensi budaya nongkrong yang terlihat seperti budaya pemalas dan tidak berguna, memiliki potensi besar untuk mengurangi stres. Lebih lanjut, budaya nongkrong juga berperan dalam meningkatkan kreativitas dalam berpikir dan berkarya. Kreativitas ini kemudian dituangkan dalam berbisnis dan usaha. Misalkan 
saja, banyaknya kafe atau kedai kopi sekarang menjadi wadah dalam memfasilitasi budaya nongkrong anakanak muda. Tidak hanya itu, tersebarnya warung kopi pun menjadi tempat nongkrong yang murah lagi merakyat.

Budaya nongkrong dapat dipahami tersendiri bagi setiap pelakunya. Ada yang menyebutkan nongkrong sebagai media penghibur diri dan berekspresi, ada pula sebagai sarana bersosialisasi. Meskipun, anggapan negatif muncul berkenaan dengan aktivitas tersebut seperti tidak produktifnya waktu, tanpa tujuan dan maksud yang jelas. Namun, budaya nongkrong menjadi aktivitas yang dinamis dan memiliki makna serta pesan tersendiri bagi para pelakunya.

\section{II.4 Anak Muda}

Pada umumnya, masa remaja atau diri anak muda merupakan masa-masa yang paling menyenangkan. Fase perkembangan pada diri anak muda menjadi masa yang rentan dan kritis. Pada tahap ini, diri remaja atau anak muda mulai mencari jati diri yang akan menentukan kehidupannya dimasa dewasa nanti. Hal ini disebabkan karena masa muda merupakan masa-masa penyempurnaan dari tahap-tahap perkembangan sebelumnya. Secara umum definisi anak muda atau remaja untuk masyarakat Indonesia memiliki batasan usia antara 11 tahun hingga 24 tahun dan belum menikah (Sarwono, 2013: 11-14).

Umumnya, para psikolog selama ini memberi label pada diri anak muda sebagai masa storm dan stress, di mana pada masa tersebut anak muda mulai menjalani proses evolusi menuju kedewasaan. Jika dikaitkan dalam tahapan sosialisasi, usia muda (11 sampai 24 tahun) terkategori dalam tahap game stage (siap bertindak) di mana individu mulai mampu mengenali perannya secara pribadi dan bersiap menuju tahap generalized stage (kedewasaan) yang mulai menjalankan perannya serta menempatkan diri di masyarakat.

\section{II.4 Landasan Teori}

Dalam melakukan studi serta pembahasan tentang fenomena budaya nongkrong anak muda di kafe, penulis menggunakan teori yang dikemukakan Baudrillard tentang masyarakat konsumsi, namun penelitian ini lebih difokuskan pada dimensi spasial konsumerisme sebagai telaah dari beberapa ranah konsumsi. Lebih jauh, fenomena tersebut dipetakan kembali sesuai ranah konsumsi yang menjadi pembentuk konsumerisme sebagai cara hidup.

Bagi Baudrillard, kultur modern saat ini memasuki era konsumerisme atau konsumsi yang bersumber dan dihasilkan melalui dunia Barat (Ashcroft et al., 2000: 296). Tahun 1970- an, Baudrillard memperlihatkan bahwa kita (masyarakat) tidak lagi hidup berdasarkan pada pertukaran barang dengan nilai guna, melainkan pada komoditas sebagai nilai tanda dan simbol yang penggunaannya bersifat sewenangwenang. Menurutnya, dalam masyarakat konsumtif, orang-orang mudah memperoleh kenikmatan atau kesenangan dengan cara membeli atau mengonsumsi sistem tanda yang dimiliki bersama (a share system of signs) (Putranto, 2005: 242).

Dalam hal ini, mengikuti kajian Baudrillard (dalam Tomlinson, 1990: 14), efek nyata dari konsumsi kontemporer terlihat pada "The passage from use value to sign value". Konsumsi tersebut, menyandarkan pada dinamika konstruksi tanda atau image serta interpretasi akan tanda tersebut. Pada fetisisme komoditas (pemuja) pun, kebutuhan individu banyak didominasi oleh objek kenikmatan (kepuasan semu) yang diperoleh dari komoditas tersebut (Ripstein, 1987). Dalam konteks ini, melihat maraknya budaya nongkrong anak muda di kafe, tak pelak memunculkan asumsi terhadap fenomena konsumerisme pada dimensi spasial. Mereka para pengguna kafe (konsumen) menyandarkan perilaku terhadap apa yang mereka pakai, kunjungi, dan gunakan. Berfoto, 
update status di berbagai media sosial seolah pembuktian diri yang 'eksis' terhadap masyarakat sekitar maupun dunia maya (facebook, instagram, path, dan sebagainya). Kebutuhan yang demikian dikaburkan oleh suatu kepuasan semu yang menjadikannya sebagai kebutuhan-kebutuhan palsu, di mana kebutuhan tersebut hadir dalam konsumerisme yang memiliki wujud berupa nilai-nilai yang didapat dalam hubungannya dengan relasi sosial. Semisal, dalam hal ini seperti status sosial, prestise, maupun citra yang melekat pada sebuah komoditas. Artinya, seluruh lanskap kontemporer ditentukan melalui kegiatan konsumsi yang bermakna bagi dirinya dan lingkungan sekitar.

Titik terpenting dalam studi konsumerisme adalah bagaimana konsumsi tersebut diinterpretasikan dan dikonstruksi melalui pijakan pengalaman sehari-hari. Melihat bagaimana budaya nongkrong di kafe sebagai gaya hidup menggambarkan fenomena konsumsi ruang akibat meningkatnya fleksibilitas bentuk produksi yang bergantung pada permintaan konsumen. Dalam konteks ini, bagaimana aktualisasi diri pada anak-anak muda terlihat melalui aktivitas konsumsi di dalam kafe melalui bentuk penyesuaian seperti meng-update status, berfoto, dan bahkan check in place di berbagai media sosial. Hal ini, tak ubahnya konsumen kian selektif dengan apa yang mereka konsumsi hanya bersifat permukaan saja, bukan lagi pada substansinya. Ini menunjukkan bagaimana para konsumen berada di bawah penindasan permainan komoditas sebagai tanda. Alhasil, lebih jauh apa yang terpenting bagi konsumen adalah nilai simbolis dari barang-barang tersebut (Soedjatmiko, 2008: 44).

Jenis data yang digunakan dalam penelitian ini menggunakan data kualitatif dalam bentuk narasi melalui informasi ataupun keterangan yang diperoleh secara langsung dari anak-anak muda (konsumen aktif) yang berdomisili di Kota Medan, baik itu laki-laki ataupun perempuan. Berikut data sekunder, data-data yang sifatnya didapat melalui pihak lain. Dalam artian, sebagai penunjang yang diperoleh melalui analisis pustaka berupa penelitina terdahulu yang berkaitan dengan objek penelitian yang mendukung data lapangan.

Analisis data yang digunakan penelitian ini adalah analisis deskriptif kualitatif. Lebih lanjut, proses analisis data dilakukan melalui tahapan reduksi data, penyajian data, hingga mencapai tahap simpulan atau verifikasi.

\section{PEMBAHASAN}

Sosmed Cafe Medan adalah cafe terbaik di Jalan Abdullah Lubis Medan Baru Kota Medan. Tersedia berbagai menu makanan, ikan, nasi goreng coffee. Sosmed Cafe dibuka pada tanggal 24 September 2018 di Kota Medan. Cafe ini sangat nyaman bagi pengunjung untuk mendapatkan pelayanan terbaik, menu makanan yang enak dan harga yang murah.

Sosmed Cafe berada di lokasi yang dekat dengan Habitat Coffee Medan. Lokasi ini berada di persimpangan Jalan Abdullah Lubis dan Simpang Jalan Sriwijaya Medan. Cafe Sosmed Cafe di kenal dengan gaya dan suasana nya yang memanjakan tamu dengan berfoto. Tempat berfoto yang unik dan ramah bagi pengunjung. Selain itu, keunikan dan keunggulan dari Sosmed Cafe terletak pada menu makanan yang unik. Cafe ini berdampingan dengan sebuah butik dari pakaian, kaos yang di jual. Ruangan yang bersih, besar dan pelayanan yang ramah.

Bagaimana rasanya makan sembari dikelilingi dekorasi serba sosial media nan lucu dan menggemaskan? Tak perlu berandai-andai lagi, sebab kini sudah ada tempat makan bernuansa ceria bernama Sosmed Cafe. Dekorasinya yang unik membuat tempat makan ini cukup populer di antara kawula muda setempat. 
Sosmed Cafe berdiri bukan hanya sekedar untuk memanjakan perut yang kelaparan, namun juga memuaskan mata. Sejauh mata memandang, tersebar sudut-sudut cantik yang seolah menggoda untuk dijadikan latar belakang foto. Para pecandu selfie dijamin bakal puas jika mengunjungi cafe unik ini. Konsep desain Sosmed Kafe ini adalah sesuai namanya, yang mengusung konsep sosial media dalam mendesain tata ruang. Di setiap sudut tampak beragam mural, dekorasi, maupun perabot bernuansa laman sosmed.

\section{III.1 Tangga}

Setiap anak tangga dihiasi grafis berbentuk logo YouTube, Facebook, Twitter, Snapchat, dan lainnya. Anak tangga menuju lantai atas pun tak luput dari sentuhan sang pendekor. Untuk lantai atas ini ternyata connected dengan lantai atasnya Restoran Nenek Moyang. Dua tempat ini memang masih berada dalam 1 managemen dan letaknya juga berdampingan.

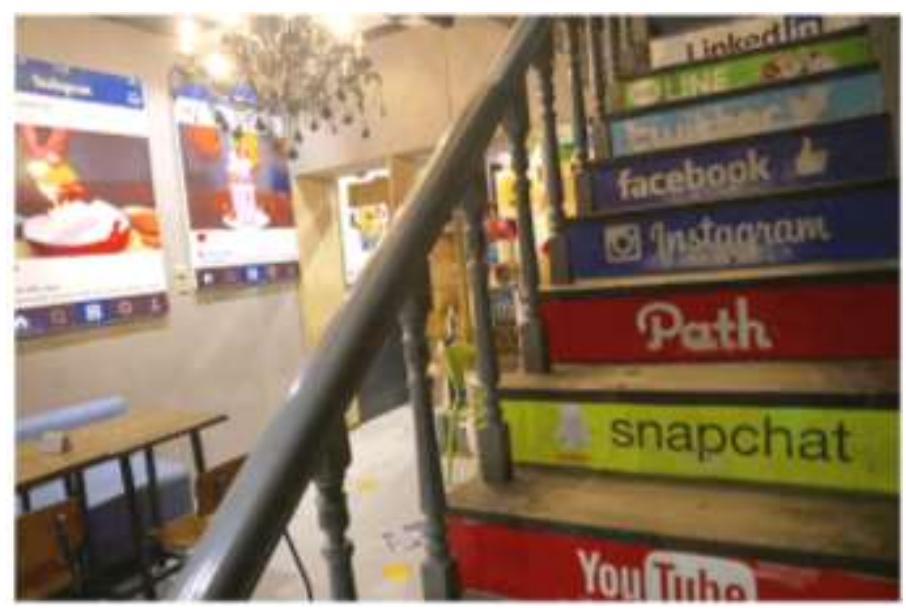

Gambar 1. Tangga Kafe Sosmed

\section{III.2 Dinding}

Dinding-dinding kafe dipenuhi pajangan foto makanan, semuanya dikemas dengan frame ala Instagram. Selain itu masih ada titik foto khusus berhiaskan boneka beruang lucu dan bumper truk dengan stiker logo YouTube. Sudut ini termasuk salah satu yang populer dan sering dimanfaatkan para pengunjung untuk berfoto-foto.

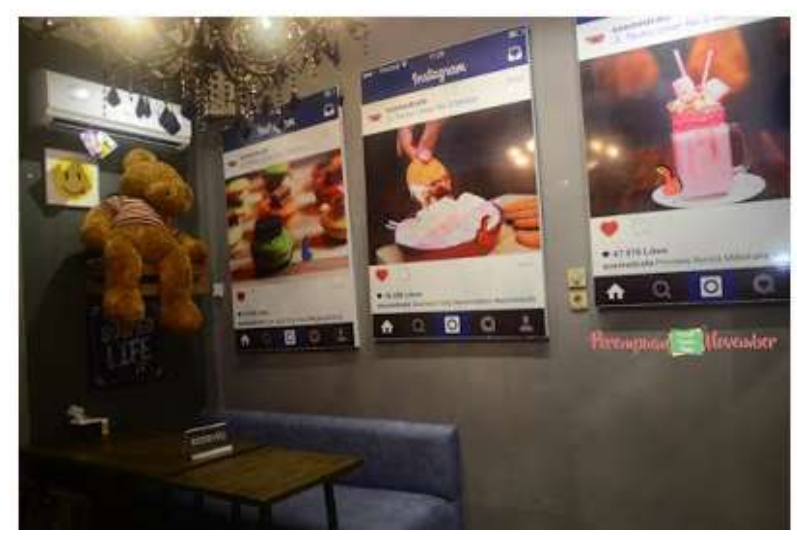

Gambar 2. Menu Makanan Pada Dinding 


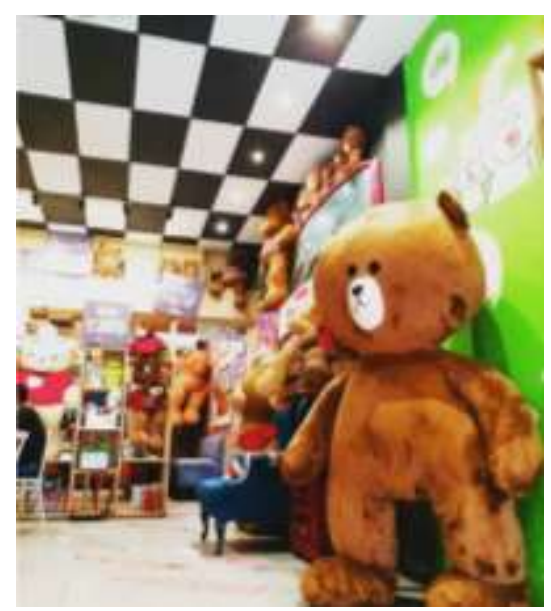

Gambar 4. Spot Foto Berselfie

Lalu ada sebuah spot yang dipasangi bemper mobil berwarna bertuliskan Youtube yang di sekelilingnya terdapat boneka-boneka beruang dengan berbagai macam bentuk dan ukuran. Spot menarik lainnya ada pada tangga kayu yang pada bagian pijakannya tertuliskan nama-nama sosial media dan aplikasi chat sehingga cocok untuk dijadikan sebagai spot selfie berikutnya. Tak hanya di lantai satu, pada lantai dua juga didesain dengan tema sosial media.

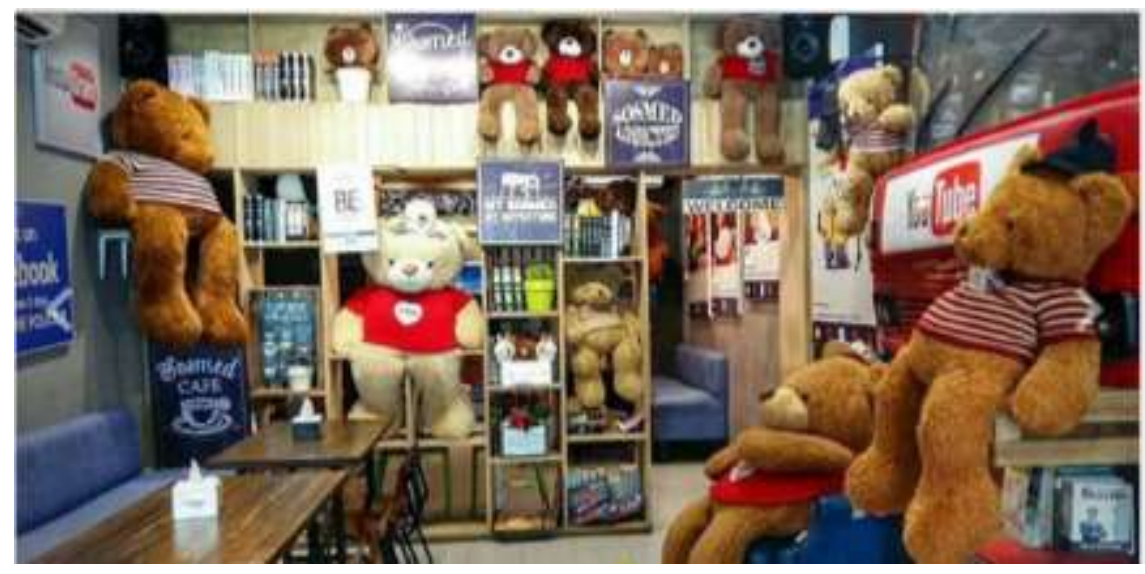

Gambar 5. Spot Foto Berselfie

\section{III.3 Makanan}

Tidak hanya soal dekorasi, Sosmed Cafe membawa konsep mereka ke level berbeda dengan menyajikan makanan yang juga bernuansa media sosial. Nasi lemak misalnya, disajikan dengan nasi yang dicetak menyerupai logo Facebook. Sementara nasi tim hadir dengan visual yang tak kalah mengejutkan, di mana nasi dan lauknya ditata hingga mirip logo Instagram. 


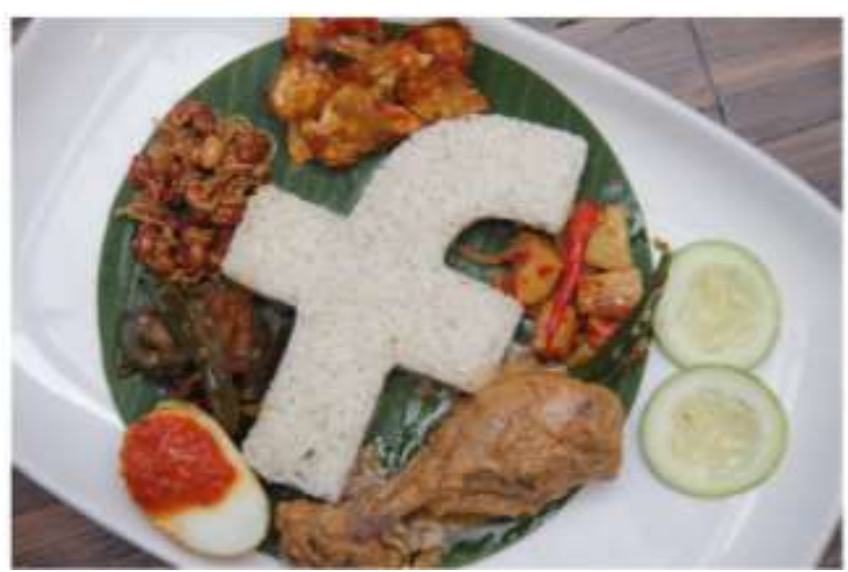

Gambar 5. Nasi Lemak Facebook

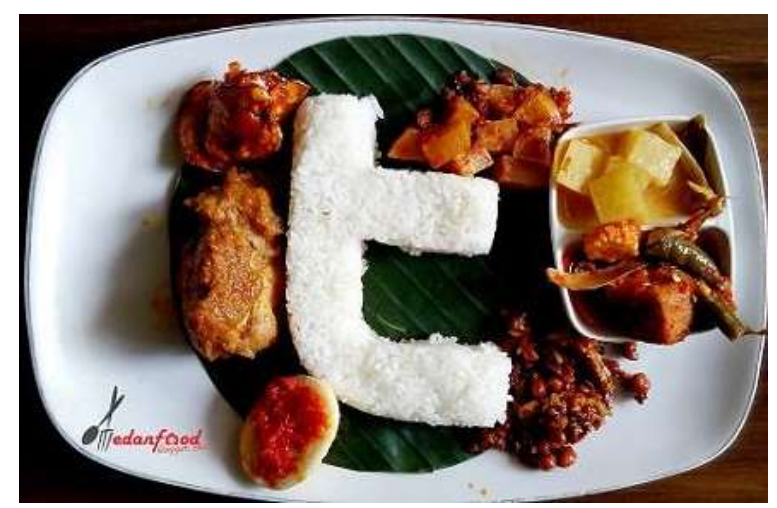

Gambar 6. Nasi Lemak Twitter

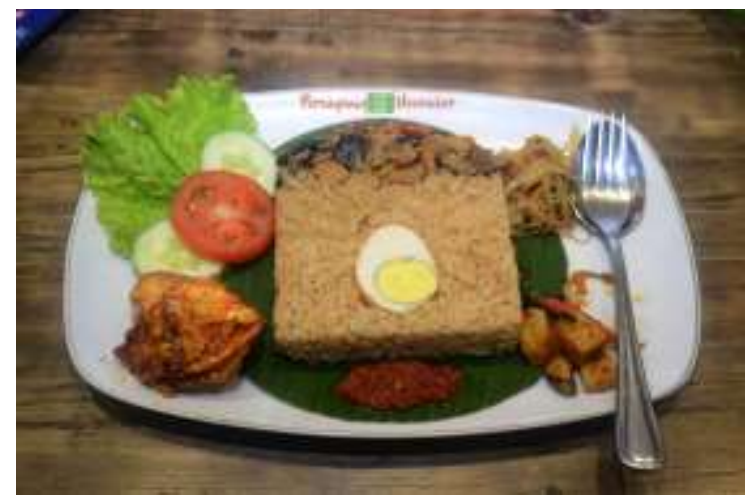

Gambar 7. Nasi Tim Intagram

Selain dua menu makanan tersebut, Sosmed Cafe juga punya menu lain yang tak kalah unik. Salah satunya adalah Mie Samyang Iblis, yang disajikan dengan garpu melayang seolah terbang. Selain itu masih ada spooky food drink yang hadir dengan tampilan mirip minuman beracun nan menyeramkan di cerita nenek sihir. 


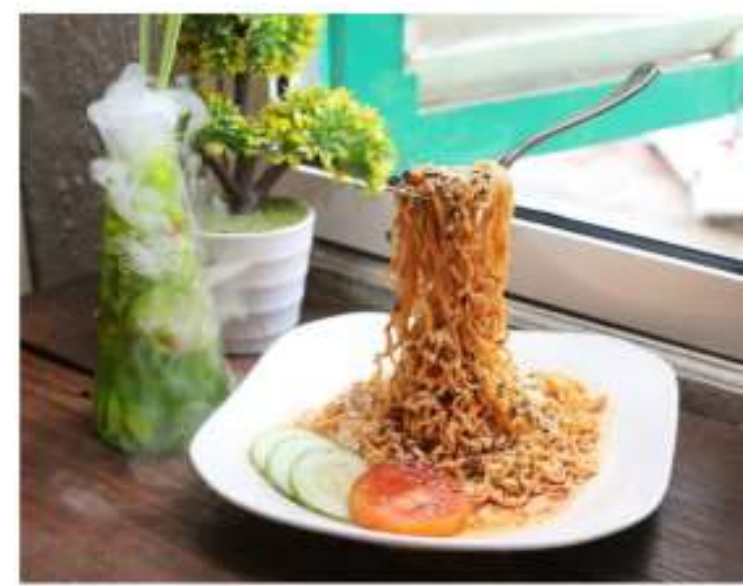

Gambar 7. Mie Samyang Iblis dan Spooky Food Drink

\section{III.4 Menu Makanan}

Selain interior kafe yang berkonsep social media, menu makanan dan minuman sengaja dicetak mirip laman Instagram. Nama-nama makanan yang disajikan juga sangat unik seperti Nasi Tim Instagram yang tampilannya dibuat seperti logo Instagram, Nasi Lemak Facebook dengan bentuk nasi berlogo Facebook, Nasi Go Green Ayam Muda, Congklak Keroyokan yang menyajikan kue cubit di dalam mainan congklak kayu, Burger Samson yang ukurannya super jumbo sehingga bisa dimakan oleh 4-5 orang, hingga Mie Samyang Iblis Gentayangan yang merupakan menu makanan favorit di Kafe Sosmed.

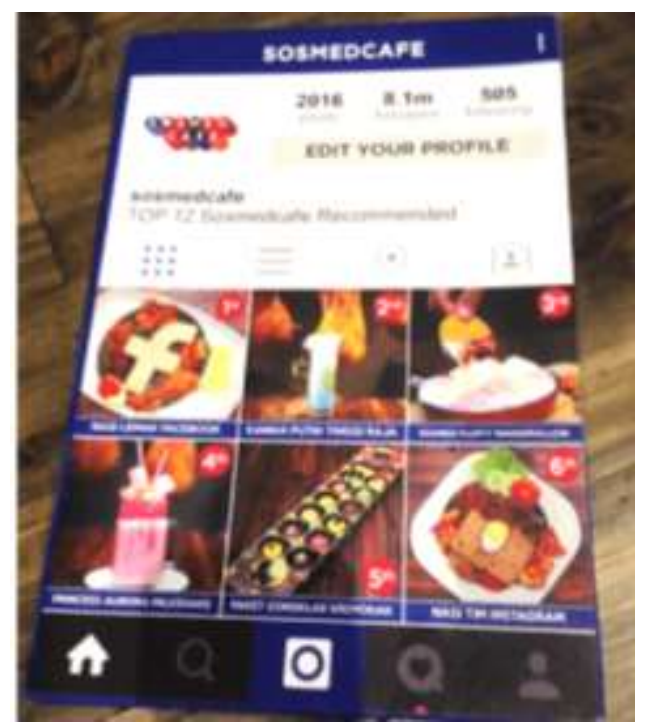

Gambar 8. Menu Makanan dan Minuman Kafe Sosmed

\section{III.5 Segmentasi Pengunjung}

1. Sikap

Sikap muda mudi yang berkunjung ke kafe Sosmed adalah untuk selalu update dan eksis di media sosial. Sejumlah muda-muda yang berkunjung ke Kafe Sosmed akan upload foto selfie ke media social mereka.

2. Pengguna

Muda-mudi memanfaatkan kafe Sosmed untuk bersantai, belajar kelompok, mengobrol bahkan untuk menghilangkan capek setelah beraktivitas seharian. 


\section{Respon konsumen}

Respon konsumen terhadap kafe Sosmed sangatlah baik. Kafe tersebut berkonsepkan media social. Semua tentang media social dituang dalam kafe ini, termasuk desain dinding, spot foto, bahkan makanan nasi berbentuk Facebook, Instagram, dan Twitter.

\section{PENUTUP}

Berikut simpulan yang dapat penulis rangkum mengenai gaya hidup nongkrong anak muda, dan menjawab rumusan masalah yang sudah di tetapkan sebelumnya.

1) Persepsi anak-anak muda terhadap merebaknya kafe kerap diasosiasikan menjadi bagian dari gaya hidup. Fenomena merebaknya kafe diberbagai sudut Kota Medan merupakan jawaban atas keberadaan serta eksistensi anak muda yang menjadikannya sarana pelepasan hasrat, selera, serta ajang pembentukan budaya serta gaya hidupnya. Keberadaannya pun menjadi sarana baru konsumsi bagi anak muda yang sekaligus sebagai bentuk distinction(jarak) antara kelas dominan dengan kelas lainnya.

2) Baik secara fungsional kafe tidak hanya sebagai tempat menikmati kopi, tempat bertemu muka atau nongkrong belaka, melainkan kafe saat ini sarat di maknai telah mengalami pergeseran nilai guna (use values) yang mengarah pada nilai tanda (sign values). Bukan lagi terletak pada kebutuhan fungsional masing-masing individu di dalamnya, melainkan berbagai motif dan kepentingan yang sifatnya lebih personal menjadi bagian dari proses konsumsi ruang kafe tersebut. Pada akhirnya, pola konsumsi juga mengalami pergeseran seiring pesatnya beragam eksterioritas yang saat ini memenuhi ruang dan tempat kafe sebagai kemasan yang unik, modern, terlebih mencitrakan setiap individu yang ada di dalamnya.

\section{DAFTAR PUSTAKA}

\section{Buku}

[1] Hornby, A S. (2005). Oxford Advance Learner's Dictionary of Current English 7 th Edition. London: Oxford University Press

[2] Kusasi, Rahayu. (2010). Globucksisasi: Meracik Globalisasi melalui Secangkir Kopi. Depok: Kepik Ungu

[3] Medlik, S. (1996). Dictionary of Travel, Tourism and Hopitality. UK: ButterworthHeinemann

[4] Oldenburg, Ray. (1989). The Great Good Place: Cafes, Coffee Shops, Bookstores, Bars, Hair Salons, and other Hangouts at The Heart of a Community. London: Da Capo Press

[5] Putranto, H. (2005). 'Analisis Budaya dari Pascamodernisme dan Pascamodernitas' dalam Sutrisno, M. \& Putranto, H. (eds). Teori-Teori Kebudayaan. Yogyakarta: Kanisius, 229-256

[6] Tomlinson, Alan (ed). (1990). Consumption, Identity, and Style: Marketing, meanings, and the packaging of pleasure. London \& New York: Routledge 
[7] Tucker, Catherine M. (2011). Coffee Culture: Local Experiences, Global Connections. New York: Routledge

\section{Jurnal}

[8] Batubara, Jose RL. (2010). Adolescent Development (Perkembangan Remaja). Jurnal Sari Pediatri, Vol 12 No 1, Juni 2010

[9] Salendra. (2014). Coffee Shop as a Media for Self-Actualization Today's Youth. Jurnal Messenger, Volume VI, Nomor 2, Juli 2014 